\title{
ECG Reporting in Children Attending Assiut University Children Hospital (Clinical Audit)
}

\author{
GHADA O. EL-SEDFY, M.D.; FAISAL EL-KHATEEB A. ABDALLAH, M.D. and \\ AL-MOATZ BELLAH Z. MOHAMMED, M.Sc. \\ The Department of Pediatrics, Faculty of Medicine, Assiut University, Egypt
}

\begin{abstract}
Background: An Electrocardiogram (ECG) may be requested as part of the investigation of a wide range of problems in pediatrics, often in patients who have no clinical evidence of cardiac disease. Frequently the request is made by practitioners with no particular expertise in cardiology. The basic principles of interpretation of the ECG in children are identical to those in adults, but the progressive changes in anatomy and physiology which take place between birth and adolescence result in some features which differ significantly from the normal adult pattern and vary according to the age of the child. Correct interpretation of the ECG is therefore potentially difficult and a detailed knowledge of these age dependent changes is critically important if errors are to be avoided.

Aim of Study: Is to evaluation of ECG interpretation and reporting competence on children attending Assiut University Children Hospital. Patients and methods the study included 90 patients over one month of age admitted in different units of Assiut Children Hospital with different causes of admission for whom ECG was one of their investigation, data of the included patients having ECG was collected and analyzed against normal value of ECG. Values were expressed in terms of percentages.
\end{abstract}

Results: Shows that from 90 ECG report only 7 (7.7\%) has even incomplete ECG reporting only heart rate, rhythm and axis were documented, the rest of data were absent. Where the other 83 cases $(92 \%)$ ECG report had no documentation and were left empty.

Conclusion: Complete ECG reporting was not done in almost all patient. Only 7 (7.7\%) had incomplete ECG report in the form of HR, rhythm and axis only. The rest of the ECG report were completely empty.

Key Words: ECG reporting - ECG interpretation.

\section{Introduction}

ELECTROCARDIOGRAPHY (ECG or EKG) is the process of recording the electrical activity of the heart over a period of time using electrodes placed on the skin. These electrodes detect the tiny

Correspondence to: Dr. Al-Moatz Bellah Z. Mohammed, E-Mail: egyptfree22@gmail.com electrical changes on the skin that arise from the heart muscle's electrophysiologic pattern of depolarization and repolarization during each heartbeat. It is a very commonly performed cardiology test [1].

An Electrocardiogram (ECG) may be requested as part of the investigation of a wide range of problems in pediatrics, often in patients who have no clinical evidence of cardiac disease. Frequently the request is made by practitioners with no particular expertise in cardiology. The basic principles of interpretation of the ECG in children are identical to those in adults, but the progressive changes in anatomy and physiology which take place between birth and adolescence result in some features which differ significantly from the normal adult pattern and vary according to the age of the child. Correct interpretation of the ECG is therefore potentially difficult and a detailed knowledge of these age dependent changes is critically important if errors are to be avoided [2] .

In a conventional 12-lead ECG, ten electrodes are placed on the patient's limbs and on the surface of the chest. The overall magnitude of the heart's electrical potential is then measured from twelve different angles ("leads") and is recorded over a period of time (usually ten seconds). In this way, the overall magnitude and direction of the heart's electrical depolarization is captured at each moment throughout the cardiac cycle. The graph of voltage versus time produced by this noninvasive medical procedure is an electrocardiogram. An understanding of the scientific basis of the ECG enables a logical interpretation of the ECG findings and an appreciation of abnormalities that may occur [3] .

The presentation of dysrhythmias can serve as a diagnostic challenge to most clinicians because 
most children present with vague and nonspecific symptoms such as "fussiness" or "difficulty of feeding". Despite the infrequent and vague presenting symptoms, it is critical to identify and appropriately manage these disorders. When left unrecognized and untreated, dysrhythmias can lead to cardiopulmonary compromise and arrest [4].

\section{The aim of this study is:}

The aim of the work is to is evaluation of ECG interpretation and reporting competence on Children attending Assiut University Children Hospital.

\section{Patients and Methods}

The study included 90 ECG reports of 90 patients admitted in different units of Assiut children hospital over one year period from 1 st of December 2016 to 1 st of December 2017 with different causes of admission.

Inclusion criteria: All patients from 1 month of age up to 18 years old attending Assuit University Children Hospital.

\section{Exclusion criteria: Neonates.}

Data collection: Data of the included patients having ECG were collected and analyzed against normal value of ECG. Values were expressed in terms of percentages.

Risk-benefit: Since there is no invasive maneuver applied to the patients or their families, so there is no risk on the patients and the benefits to improve documentation of ECG reporting.

The following data were collected and recorded for each patient in ECG report used in Assuit University Children Hospital:

1-Socio-demographic data such as name, age and sex.

2- Data about associated conditions: Congenital heart disease, respiratory disease, down syndrome and other indication of ECG.

3- Data about ECG interpretation. Checking ECG report for each patient regarding documentation of all data i.e clinical notes, HR, Rhythm, .....etc.

4- Data about investigations such as chest X-ray, echocardiography and others.

Data management and analysis:

Data of the included patients having ECG were collected and analyzed against normal value of ECG. Values were expressed in terms of percentages.

\section{Results}

The study included 90 ECG reports of 90 patients admitted in different units of Assiut Children Hospital over one year period from 1 st of December 2016 to 1 st of December 2017 with different causes of admission, patients were arranged in to groups according to age to correlate their result with the normal reference of ECG, out of the studied cases, $47(52.2 \%)$ were males and $43 \%(47.8)$ were females. According to the age distribution, $10(11.1 \%)$ of cases were from 1 month to 2 months, 28 (31.1\%) of cases were from 3 months to 5 months, 21 (23.3\%) of cases were from 6 months to 11 months, $20(22.2 \%)$ of cases were from 1 years to 2 years, $6(6.7 \%)$ of cases were from 3 years to 4 years, 2 $(2.2 \%)$ of cases were from 8 years to 11 years, 2 (2.2\%) of cases were from 12 years to 15 years, 1 $(1.1 \%)$ of cases were above 16 years, the mean age \pm SD was $(18.58 \pm 35.83)$ months.

Table (1): The demographic data of studied cases.

\begin{tabular}{|c|c|c|}
\hline & No. & $\%$ \\
\hline \multicolumn{3}{|l|}{ Sex: } \\
\hline Total & 90 & 100 \\
\hline Male & 47 & 52.2 \\
\hline Female & 43 & 47.8 \\
\hline \multicolumn{3}{|l|}{ Age level: } \\
\hline 1-2 months & 10 & 11.1 \\
\hline 3-5 months & 28 & 31.1 \\
\hline 6-11 months & 21 & 23.3 \\
\hline $1-2$ years & 20 & 22.2 \\
\hline $3-4$ years & 6 & 6.7 \\
\hline $8-11$ years & 2 & 2.2 \\
\hline $12-15$ years & 2 & 2.2 \\
\hline$>16$ years & 1 & 1.1 \\
\hline \multicolumn{3}{|c|}{ Table (2): Reporting cases to not reporting ratio. } \\
\hline \multirow[b]{2}{*}{ Total } & \multicolumn{2}{|c|}{90 cases } \\
\hline & $\begin{array}{c}\text { Incomplete reporting } \\
\text { No. }(\%)\end{array}$ & $\begin{array}{l}\text { Not reporting } \\
\text { No. }(\%)\end{array}$ \\
\hline ECG report & $7(7.7 \%)$ & $83(92.3 \%)$ \\
\hline \multicolumn{3}{|l|}{ Pediatric units: } \\
\hline Cardiology Unit & $3(3.3 \%)$ & $54(60 \%)$ \\
\hline ICU & $2(2.2 \%)$ & $3(3.3 \%)$ \\
\hline GIT Unit & $0(0 \%)$ & $10(11.1 \%)$ \\
\hline Emergency Unit & $2(2.2 \%)$ & $18(20 \%)$ \\
\hline
\end{tabular}

Table (2) shows that from 90 ECG report only $7(7.7 \%)$ has even incomplete ECG reporting where only heart rate, rhythm and axis were documented, The rest of data were absent. The other 83 cases (92\%) ECG reports had no documentation and were left empty. 
Table (3): Heart rate, PR interval QRS duration interpretation.

\begin{tabular}{|c|c|c|c|}
\hline \multirow{2}{*}{$\begin{array}{l}\text { Total } \\
\text { Age } \\
\text { range }\end{array}$} & \multicolumn{3}{|c|}{90} \\
\hline & $\begin{array}{c}\text { HR } \\
\text { No. }(\%)\end{array}$ & $\begin{array}{l}\text { PR interval } \\
\text { No. }(\%)\end{array}$ & $\begin{array}{l}\text { QRS duration } \\
\text { No. }(\%)\end{array}$ \\
\hline \multicolumn{4}{|l|}{ 1-2 months: } \\
\hline Normal & $8(80 \%)$ & $0(0 \%)$ & $6(60 \%)$ \\
\hline Abnormal & $2(20 \%)$ & $10(100 \%)$ & $4(40 \%)$ \\
\hline \multicolumn{4}{|l|}{ 3-5 months: } \\
\hline Normal & $26(92.9 \%)$ & $18(64.3 \%)$ & $20(71.4 \%)$ \\
\hline Abnormal & $2(7.1 \%)$ & $10(35.7 \%)$ & $8 \quad(28.6 \%)$ \\
\hline \multicolumn{4}{|l|}{ 6-11 months: } \\
\hline Normal & $14(66.7 \%)$ & $16(76.2 \%)$ & $16(76.2 \%)$ \\
\hline Abnormal & $7 \quad(33.3 \%)$ & $5 \quad(23.8 \%)$ & $5 \quad(23.8 \%)$ \\
\hline \multicolumn{4}{|l|}{ 1-2 years: } \\
\hline Normal & $14(7 \%)$ & $15(75 \%)$ & $16(8 \%)$ \\
\hline Abnormal & $6 \quad(30 \%)$ & $5(25 \%)$ & $4(20 \%)$ \\
\hline \multicolumn{4}{|l|}{ 3-4 years: } \\
\hline Normal & $2(33.3 \%)$ & $6(100 \%)$ & $6(100 \%)$ \\
\hline Abnormal & $4(66.7 \%)$ & $0(0 \%)$ & $0(0 \%)$ \\
\hline \multicolumn{4}{|l|}{$8-11$ years: } \\
\hline Normal & $2(100 \%)$ & $2(100 \%)$ & $2(100 \%)$ \\
\hline Abnormal & $0(0 \%)$ & $0(0 \%)$ & $0(0 \%)$ \\
\hline \multicolumn{4}{|l|}{ 12-15 years: } \\
\hline Normal & $0(0 \%)$ & $2(100 \%)$ & $0(0 \%)$ \\
\hline Abnormal & $2(100 \%)$ & $0(0 \%)$ & $2(100 \%)$ \\
\hline \multicolumn{4}{|l|}{$>16$ years: } \\
\hline Normal & $0(0 \%)$ & $1(100 \%)$ & $0(0 \%)$ \\
\hline Abnormal & $1(100 \%)$ & $0(0 \%)$ & $1(100 \%)$ \\
\hline
\end{tabular}

As shown in (Table 3) shows heart rate, PR interval and QRS duration interpretation incoresponding with normal value of ECG were found.

At age group from (1-2 months) 10 cases (11.1\%):

Normal HR in 8 cases $(80 \%)$, and abnormal HR in 2 cases (2\%) (tachycardia). All cases had abnormal PR interval, normal QRS duration in 6 cases $(60 \%)$ and abnormal in $4(40 \%)$.

At age group from (3-5 months) 28 cases (31.1\%):

Normal HR in 26 cases $(92.9 \%)$ and abnormal HR in 2 cases (7.1\%) (tachycardia). Normal PR interval in $18(64.3 \%)$ and abnormal in $10(35.7 \%)$. Normal QRS duration in 20 (71.4\%) and abnormal in $8(28.6 \%)$.

At age group from (6-11 months) 21 cases (23.3\%):

Normal HR in $14(66.7 \%)$ and abnormal HR in $7(33.3 \%)$ (tachycardia). Normal PR interval in $16(76.2 \%)$ and abnormal in $0(0 \%)$. Normal QRS Duration in $16(76.2 \%)$ and abnormal in $5(23.8 \%)$.

At age group from (1-2 years) 20 cases (22.2\%):

Normal HR in $14(7 \%)$ and abnormal HR in 6 (30\%). Normal PR interval in $15(75 \%)$ and abnormal in $5(25 \%)$. Normal QRS duration in 16 $(76.2 \%)$ and abnormal in $4(20 \%)$.
At age group from (3-4 years) 6 cases $(6.7 \%)$ :

Normal HR in $2(33.3 \%)$ and abnormal HR in $4(66.7 \%)$. Normal PR interval and QRS duration.

At age group from (8-11 years) 2 cases $(2.2 \%)$ :

Normal HR QRS duration and PR interval in $2(100 \%)$ and abnormal in $0(0 \%)$.

At age group from (12-15 years) 2 cases (2.2\%):

Normal HR. PR interval and QRS duration in $2(100 \%)$. And abnormal in $0(0 \%)$.

At age group above (16 years) 1 cases (1.1\%):

Normal PR interval in $1(100 \%)$ and abnormal in $0(0 \%)$. Abnormal HR, QRS duration in 2 $(100 \%)$.

Table (4): $\mathrm{R}$ wave and $\mathrm{S}$ wave interpretation.

\begin{tabular}{|c|c|c|c|c|}
\hline Age range & $\begin{array}{c}\text { R V1 } \\
\text { No. }(\%)\end{array}$ & $\begin{array}{c}\text { S V1 } \\
\text { No. }(\%)\end{array}$ & $\begin{array}{c}\text { R V6 } \\
\text { No. }(\%)\end{array}$ & $\begin{array}{c}\text { S V6 } \\
\text { No. }(\%)\end{array}$ \\
\hline \multicolumn{5}{|l|}{ 1-2 months: } \\
\hline Normal & $6(60 \%)$ & $10(100 \%)$ & $6(60 \%)$ & $6(60 \%)$ \\
\hline Abnormal & $4(40 \%)$ & $0(0 \%)$ & $4(40 \%)$ & $4(40 \%)$ \\
\hline \multicolumn{5}{|l|}{ 3-5 months: } \\
\hline Normal & $22(78.6 \%)$ & $24(85.7 \%)$ & $13(46.4 \%)$ & $16(57.1 \%)$ \\
\hline Abnormal & $6 \quad(21.4 \%)$ & $4 \quad(14.3 \%)$ & $15(53.6 \%)$ & $12(42.9 \%)$ \\
\hline \multicolumn{5}{|l|}{ 6-11 months: } \\
\hline Normal & $17(81.0 \%)$ & $19(90.5 \%)$ & $16(76.2 \%)$ & $13(61.9 \%)$ \\
\hline Abnormal & $4 \quad(19.1 \%)$ & $2 \quad(9.5 \%)$ & $5 \quad(23.8 \%)$ & $8 \quad(38.1 \%)$ \\
\hline \multicolumn{5}{|l|}{ 1-2 years: } \\
\hline Normal & $18(90 \%)$ & $16(80 \%)$ & $18(90 \%)$ & $18(90 \%)$ \\
\hline Abnormal & $2(10 \%)$ & $4(20 \%)$ & $2(10 \%)$ & $2(10 \%)$ \\
\hline \multicolumn{5}{|l|}{ 3-4 years: } \\
\hline Normal & $4(66.7 \%)$ & $6(100 \%)$ & $4(66.7 \%)$ & $2(33.3 \%)$ \\
\hline Abnormal & $2(33.3 \%)$ & $0(0 \%)$ & $2(33.3 \%)$ & $4(66.7 \%)$ \\
\hline \multicolumn{5}{|l|}{ 8-11 years: } \\
\hline Normal & $0(0 \%)$ & $2(100 \%)$ & $2(100 \%)$ & $0(0 \%)$ \\
\hline Abnormal & $2(100 \%)$ & $0(0 \%)$ & $0(0 \%)$ & $2(100 \%)$ \\
\hline \multicolumn{5}{|l|}{ 12-15 years: } \\
\hline Normal & $2(100 \%)$ & $2(100 \%)$ & $0(0 \%)$ & $0(0 \%)$ \\
\hline Abnormal & $0(0 \%)$ & $0(0 \%)$ & $2(100 \%)$ & $2(100 \%)$ \\
\hline \multicolumn{5}{|l|}{$>16$ years: } \\
\hline Normal & $1(100 \%)$ & $1(100 \%)$ & $1(100 \%)$ & $0(0 \%)$ \\
\hline Abnormal & $0(0 \%)$ & $0(0 \%)$ & $0(0 \%)$ & $1(100 \%)$ \\
\hline
\end{tabular}

As shown in (Table 4) according to ECG findings incoresponding with normal value of ECG were found.

At age group from (1-2 months) 10 cases (11.1\%):

Regarding $\mathrm{S}$ wave and $\mathrm{R}$ wave interpretation, There were normal $\mathrm{S}$ wave in $\mathrm{V} 1$ in 10 cases (100\%). Normal RV1, RV6, SV6 in 6 cases $(60 \%)$ and abnormal in $4(40 \%)$ in the form of tall $\mathrm{R}$ wave and deep $\mathrm{S}$ wave.

At age group from (3-5 months) 28 cases (31.1\%):

Regarding $\mathrm{S}$ wave and $\mathrm{R}$ wave interpretation, There were normal RV 1 in 22 (78.6\%) and abnor- 
mal in $6(21.4 \%)$. Normal R V6 in 13 (46.4\%) and abnormal in $15(53.6 \%)$ in the form of tall $\mathrm{R}$ wave in the form of tall R wave. Normal S V1 in $24(85.7 \%)$ and abnormal in $4(14.3 \%)$. Normal $\mathrm{S}$ V6 in $16(57.1 \%)$ and abnormal in $12(42.9 \%)$ in the form of deep $\mathrm{S}$ wave.

\section{At age group from (6-11 months) 21 cases (23.3\%):}

Regarding $\mathrm{S}$ wave and $\mathrm{R}$ wave interpretation, There were normal R V1 in $17(81.0 \%)$ and abnormal 4 (19.1\%). Normal R V6 in $16(76.2 \%)$ and abnormal in $5(23.8 \%)$ in the form of tall $\mathrm{R}$ wave in the form of tall R wave. Normal S V1 in 19 $(90.5 \%)$ and abnormal in $2(9.5 \%)$. Normal S V6 in $13(61.9 \%)$ and abnormal in $8(38.1 \%)$ in the form of deep $\mathrm{S}$ wave.

At age group from (1-2 years) 20 cases (22.2\%):

Regarding $\mathrm{S}$ wave and $\mathrm{R}$ wave interpretation, There were normal S V1 in $16(76.2 \%)$ and abnormal in $4(20 \%)$. Normal R V1-R V6-S V6 in 18 $(90 \%)$ and abnormal in $2(10 \%)$ in the form of tall $\mathrm{R}$ wave and deep $\mathrm{S}$ wave.

At age group from (3-4 years) 6 cases (6.7\%):

Regarding $\mathrm{S}$ wave and $\mathrm{R}$ wave interpretation, there were normal S V1 in $6(100 \%)$, S V 6 in 2
$(33.3 \%)$ and abnormal in $4(66.7 \%)$. Normal S V1 in $6(100 \%)$ and abnormal in $0(0 \%)$ in the form of deep S wave. Normal R V1 and R V6 in 4 $(66.7 \%)$ and abnormal in $2(33.3 \%)$ in the form of tall $\mathrm{R}$ wave.

At age group from (8-11 years) 2 cases (2.2\%):

Regarding $\mathrm{S}$ wave and $\mathrm{R}$ wave interpretation, There were normal S V 1and RV 1 in $2(100 \%)$ and abnormal in $0(0 \%)$. Abnormal RV1 and SV6 in 2 $(100 \%)$ in the form of tall $\mathrm{R}$ wave and deep $\mathrm{S}$ wave.

At age group from (12-15 years) 2 cases (2.2\%):

Regarding $\mathrm{S}$ wave and $\mathrm{R}$ wave interpretation, There were normal S V1 and RV6 in $2(100 \%)$ and abnormal in $0(0 \%)$. Abnormal RV6 and SV6 in 2 $(100 \%)$ in the form of tall $\mathrm{R}$ wave and deep $\mathrm{S}$ wave.

At age group above (16 years) 1 cases (1.1\%):

Regarding $\mathrm{S}$ wave and $\mathrm{R}$ wave interpretation, There were normal S V6. RV6 and RV1 in $1(100 \%)$ and abnormal in $0(0 \%)$. Abnormal S V 1 in $2(100 \%)$ in the form of deep $\mathrm{S}$ wave.

Table (5): QRS and T axis interpretation.

\begin{tabular}{|c|c|c|c|c|c|c|c|c|c|c|c|c|c|c|c|c|}
\hline \multirow{3}{*}{ Total } & \multicolumn{16}{|c|}{90 cases } \\
\hline & \multicolumn{2}{|c|}{ 1-2 months } & \multicolumn{2}{|c|}{ 3-5 months } & \multicolumn{2}{|c|}{ 6-11 months } & \multicolumn{2}{|c|}{$1-2$ years } & \multicolumn{2}{|c|}{$3-4$ years } & \multicolumn{2}{|c|}{ 8-11 years } & \multicolumn{2}{|c|}{$12-15$ years } & \multicolumn{2}{|c|}{$>16$ years } \\
\hline & No. & $\%$ & No. & $\%$ & No. & $\%$ & No. & $\%$ & No. & $\%$ & No. & $\%$ & No. & $\%$ & No. & $\%$ \\
\hline \multicolumn{17}{|l|}{ QRS-Axis: } \\
\hline Normal & 10 & 11.1 & 14 & 15.6 & 17 & 18.9 & 18 & 20.0 & 4 & 4.4 & 0 & 0.0 & 0 & 0.0 & 1 & 1.1 \\
\hline Right & 0 & 0.0 & 10 & 11.1 & 4 & 4.4 & 2 & 2.2 & 2 & 2.2 & 2 & 2.2 & 2 & 2.2 & 0 & 0.0 \\
\hline Left & 0 & 0.0 & 4 & 4.4 & 4 & 0.0 & 0 & 0.0 & 0 & 0.0 & 0 & 0.0 & 0 & 0.0 & 0 & 0.0 \\
\hline \multicolumn{17}{|l|}{ T-Axis: } \\
\hline Normal & 10 & 11.1 & 28 & 31.1 & 19 & 22.2 & 20 & 22.2 & 6 & 6.7 & 2 & 2.0 & 2 & 2.0 & 1 & 1.1 \\
\hline Abnormal & 0 & 0.0 & 0 & 0.0 & 2 & 0.0 & 0 & 0.0 & 0 & 0.0 & 0 & 0.0 & 0 & 0.0 & 0 & 0.0 \\
\hline
\end{tabular}

Table (5) regarding to QRS interpretation, it was found that there is right axis deviation in 22 $(24.45 \%)$, it was found that there is left axis deviation in $4(4.4 \%)$, while normal axis deviation in $56(62.2 \%)$. And regarding $\mathrm{T}$ axis interpretation, it was found that there is normal axis in $88(97.7 \%)$ and abnormal T-Axis in $2(2.2 \%)$ cases.

Table (6): Clinical diagnosis of studied cases.

\begin{tabular}{lll}
\hline \multicolumn{3}{c}{ Total 90 cases } \\
\hline \multicolumn{1}{c}{ ongential heart disease } & $\begin{array}{c}\text { Abnormal } \\
\text { rhythm }\end{array}$ & \multicolumn{1}{c}{$\begin{array}{c}\text { Rheumatic } \\
\text { HD }\end{array}$} \\
\hline $\begin{array}{l}\text { Non cyanotic CHD: } 64(71.1 \% \\
\text { fallot s tetralogy: } 11(12.2 \%)\end{array}$ & SVT: & Rheumatic activity \\
DORV: $5(5.5 \%)$ & & $4(4.4 \%)$ \\
\hline
\end{tabular}

As shown in (Table 6) according to echo findings and radiological findings there were 80 $(88.8 \%)$ cases with congential heart disease, 64 $(71.1 \%)$ of them were non cyanotic CHD, 11 $(12.2 \%)$ were fallot s tetralogy, $5(5.5 \%)$ were DORV. Others cases $6(6.6 \%)$ having abnormal rhythm in the form of SVT, and 4 (4.4\%) cases having rheumatic activity.

\section{Conclusion:}

- Complete ECG reporting was not done in almost all patient.

- Only 7 (7.7\%) had incomplete ECG report in the form of HR, rhythm and axis only. 
- The rest of the ECG report were completely empty.

\section{Recommendations:}

- ECG reporting should be completed and not to leave any part of ECG report without interpretation.

-ECG report form, which is used in Assiut Children Hospital, is a good tool for diagnosis of many pediatric disease and does not need any up dating.

\section{References}

1- CHAKRABARTI S. and STUART A.G.: Understanding cardiac arrhythmias. Archives of Disease in childhood, 90: 1086-90, 2005

2- BATRA S.A. and MOHARI N.: Junctional ectopic tachycardia: Current strategies for diagnosis and management. Progress in Pediatric. Cardiology Journal, Volume 35, P49-54, 2013.

3- BEHR E.R., DALAGEORGOU C., CHRISTIANSEN M., et al.: Sudden arrhythmic death syndrome: Familial evaluation identifies inheritable heart diseas in the majority of families. Eur. Heart J., Volune 29: p. 1670-10, 2008.

4- GEORGE F. and VAN: Disturbances of Rate and Rhythm of the Heart. In: Robert M. Kilegman (Editor-in-chief): Nelson Text Book of Pediatrics. edition, Philadelphia, Ch. 429 p. 1613, 2011.

5- SURAWICZ, BORYS, KNILLANS, TIMOTHY, et al.: Chou's electrocardiography in clinical practice: Adult and pediatric $\left(6 \mathrm{t}^{\mathrm{h}}\right.$ ed.). Philadelphia, PA: Saunders/Elsevier. p. 12. ISBN 1416037748, 2008.

6- RARDON D.P., MILES W.M. and ZIPES D.P.: Atrioventricular block and dissociation. In: Zipes D.P., Jalife J., editors. Cardiacelectrophysiology: From cell to bedside. 3 rd edition. Philadelphia: WBSaunders, p. 451-9, 2000.
7- FRIDAY R.Y., ROSS P.A., McDANIEL N.A., et al.: In Chan T.C., Brady W.J., Harrigan R.A., et al., editors. Congenital heart disease. Philadelphia: Elsevier/Mosby, p. 238-52, 2005.

8- NICHOLAS H., VON BERGEN and IAN H.L.: AV nodal reentrant tachycardia in children: Current approaches to. management. Progress in Pediatric Cardiology Journal, Volume 35, p. 25-32, 2013.

9- GAJEWSKI K.K., ROBERTSON J., SHILKOFSKI N., et al.: Johns Hopkins the Harriet Lane Handbook: A manual for pediatric house officers. $17^{\text {th }}$ edition. St. Louis (MO): Mosby, p. 159-209, 2005.

10-HANASH R.C. and CROSSON E.J.: Emergency diagnosis and management of pediatric arrhythmias. Journal of Emergencies, Trauma and Shock, Jul.-Sep., Volume 3 (3): p. 251-60, 2010.

11- JIN, BENJAMIN E., WULFF, et al.: (December). "A simple device to illustrate the Einthoven triangle". Advances in Physiology Education, 36 (4): 319-24, 2012.

12- KLIGFIELD, PAUL; GETTES, LEONARD S., et al.: (2007-03-13). "Recommendations for the standardization and interpretation of the electrocardiogram: Part I: The electrocardiogram and its technology: A scientific statement from the American Heart Association Electrocardiography and Arrhythmias Committee, Council on Clinical Cardiology; the American College of Cardiology Foundation; and the Heart Rhythm Society: Endorsed by the International Society for Computerized Electrocardiology". Circulation, 115 (10): 1306-24.

13- ZIEGLER V.L. and GILLETTE P.C.: Editors. Practical management of pediatric cardiac arrhythmias. Armonk NY: Futura Publishing Co., Inc., 2001.

14- DROSSNER M.D., HIRSH A.D., et al.: Cardiac disease in pediatric patients presenting to a pediatric ED with chest pain.American Journal of Emergency Medicine, Volume 29, p. 632-8, 2011. 


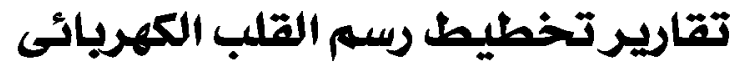 للآطفال المترددين على مستشفى الآطفال الجامعى الجمي (دراسة تدقيقية)}

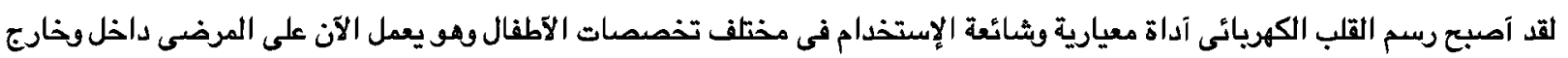

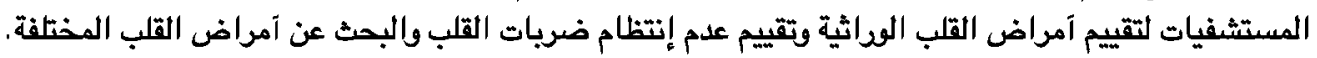

إن الهدف من هذا البحث هو توضيح رسم القلب الكهربائى وكتابة تقرير للآلطفال المتردين على مستثفى الآطفال الجامعى بآسيوط. إن رسم القلب الكهربائى يمكن آن يطلب كجزء من الفحوصات لعديد من مشاكل الآطفال خاصة هؤلاء الذين لا توجد لديهم آعراض واضحة لمرض القلب وعادة الفحص يطلب بواسطة آطباء ليس لديهم خبرة في طب الب قلب الآطفال.

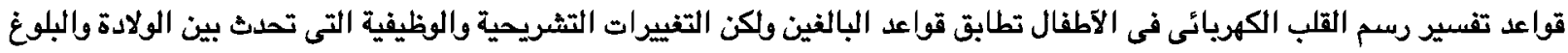

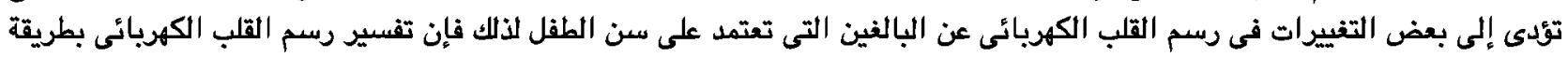
صحيحة صعب ويحتاع إلى معرفة مفصلة عن هذه التغييرات مع السن.

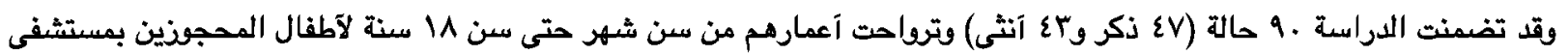

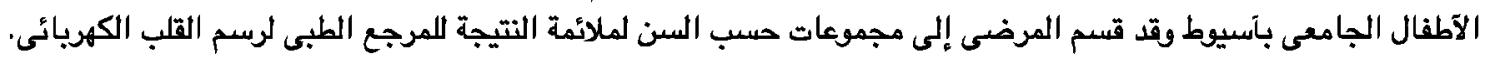

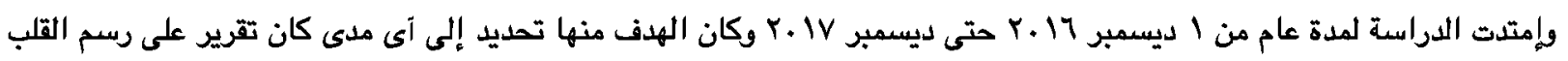

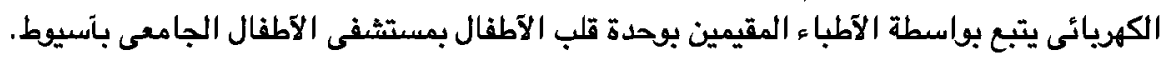

وأوضحت النتائج آن ل حالات فقط هم من تم عمل تقارير رسم تلب كهريائى لهم وكان غير مكتمل وبه حالة لم يتم عمل آى تقرير على رسم القلب الكهربائى الخاص بهم.

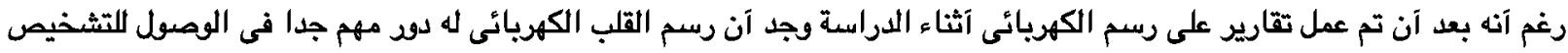

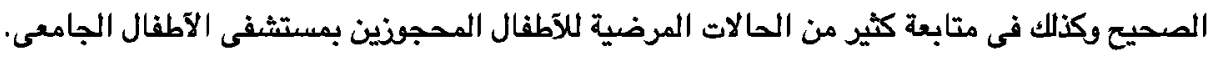

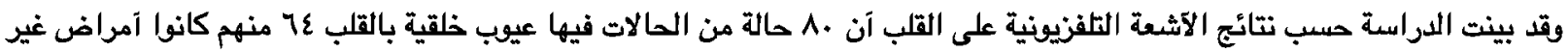

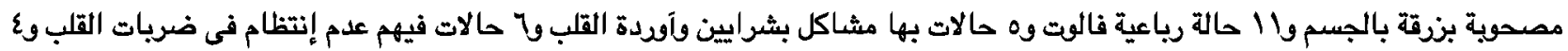
حالات فيهم نثاط روماتيزمى. بزئ. 